Piotr Jordan Śliwiński

ORCID: https://orcid.org/0000-0002-2833-063X

Uniwersytet Jagielloński

\title{
Nauczyć się swojego domu. Mieszkania treningowe - trening w mieszkaniu
}

\author{
To learn one's home. \\ Training apartments - training in an apartment
}

\begin{abstract}
In the landscape of a large Polish city, one can notice homeless people, but also activities that help them survive in this difficult state and go out of it. In Cracow, such activities are undertaken, among others, by the Saint Father Pio Aid Centre. One of the phases of getting out of homelessness is staying at a "training flat", the aim of which is for a person to learn to look after a flat and manage their earned resources. Based on observation, analysis of documents and interviews with employees of the Centre, the article tries to show the difficult path to "learn one's home".
\end{abstract}

Key words: training flat, homelessness, help for the homeless

W krajobrazie dużego polskiego miasta zauważyć można bezdomnych, wobec których inicjowane są liczne działania mające pomóc im przetrwać w tym trudnym stanie oraz z niego wyjść. W Krakowie podejmuje je między innymi Dzieło Pomocy św. Ojca Pio. Jedną z faz wychodzenia z bezdomności jest pobyt w „mieszkaniu treningowym”. Celem jest nauczenie się troski o mieszkanie i odpowiedniego gospodarowania zarobionymi środkami. W artykule, na podstawie obserwacji, analizy dokumentów oraz wywiadów z pracownikami Dzieła, podjęto próbę pokazania niełatwej drogi do „nauczenia się swojego domu”.

Słowa kluczowe: mieszkanie treningowe, bezdomność, pomoc bezdomnym

Odebrano / Received: 31.01.2019

Zaakceptowano / Accepted: 27.08.2019 
Uczenie się domu nie wydaje się niczym zaskakującym w pewnych sytuacjach życiowych. Dziecko, rosnąc i rozwijając się nie tylko fizycznie, ale i społecznie, poznaje granice nie tylko swego ciała, ale te tego, co do niego i jego rodziny należy, w tym także granice własnej przestrzeni. Ten pokój jest jego, to mieszkanie należy „do nas”, czyli do jego rodziny. Wraz z rozwojem tej świadomości przybywa obowiązków związanych ze wspólną przestrzenią. Dziecko uczy się ją identyfikować ze względu na funkcję, jaką pełnią jej części (jadalnia, pokój dzienny, sypialnia, łazienka). Uczy się także dzielić przestrzeń z innymi osobami - nieraz nie bez konfliktów - bo dane miejsce przy stole czy przed telewizorem jest również preferowane przez innych domowników. Odpowiedzialność za zajmowaną przestrzeń nakłada obowiązek dbałości o nią. Dzieci uczą się utrzymywać porządek poprzez składanie zabawek, sprzątanie biurka do nauki, włączają się w prace domowe obejmujące zarówno własny pokój, jak i przestrzeń zajmowaną wspólnie z innymi domownikami. I choć różne urządzenia ułatwiają człowiekowi zadbanie o własny dom (reklama czyni ze sprzątania wręcz zabawę - „I wszystko czyste!"), to jednak zajęcia związane z porządkowaniem pochłaniają sporo czasu i wymagają wysiłku. A przecież to nie jedyna forma troski o zajmowane mieszkanie - trzeba regularnie uiszczać opłaty, dbać o funkcjonujące w domu systemy itd. Tej troski trzeba się uczyć i naturalny jest wraz wiekiem wzrost zaangażowania w utrzymanie porządku w domu. Własne mieszkanie ma wyznaczać nie tylko przestrzeń zamieszkania, choć jest to jego najważniejsze znaczenie, ale także - metaxu - w rozumieniu Simone Weil, która tym pojęciem obejmuje zjawiska, które odsyłają, wskazują na coś innego ${ }^{1}$, odnosząc je do rzeczy doczesnych, spotykanych tu i teraz, pośredniczących w dążeniu do ostatecznego celu człowieka, jakim jest Bóg i wieczne bycie z Nim. Rzeczy te są, aby kiedyś ostatecznie móc się bez nich obejść. Dla Weil cały świat jest tylko drogą do Boga²

Gorzej, gdy ktoś zostaje pozbawiony lub sam pozbawia się domu. Bezdomność oducza troski o przestrzeń, w której się przebywa, albo raczej zasadniczo ją zmienia ograniczając wyłącznie do jej względnego zabezpieczenia przed zagrożeniami zewnętrznymi. O wyborze miejsca do życia decydują zarówno możliwa do zniesienia temperatura, brak cieków wodnych, odległość od wysypiska szkodliwych odpadów, jak i brak szczególnych przejawów agresji ze strony okolicznych mieszkańców ${ }^{3}$. Analizą przyczyn zjawiska bezdomności w Polsce zajmowali się kompetentnie rozliczni badacze, zwłaszcza socjolodzy. W niniejszym tekście przedstawię strategię przeciwdziałania bezdomności, pomocy w wychodzeniu z niej, realizowaną w Dziele Pomocy św. Ojca Pio w Krakowie,której częściąjest etap przebywania w mieszkaniu wspieranym. Wykorzystam w tym celu informacje zebrane od pracowników Dzieła oraz własne obserwacje

1 Weil 1986. Pojęcie to jest proweniencji greckiej kategoria metaxu ( $\mu \varepsilon \tau \alpha \xi u ́)$, pojawia się choćby u Platona, ale tutaj zatrzymamy się przy sensie, jaki nadaje mu S. Weil.

2 Weil 1986, $273 \mathrm{nn}$.

3 Oliwa-Ciesielska 2004. 
poczynione podczas wolontariatu w Dziele. Wydaje się, że dla zrozumienia działań na rzecz „zadomowiania” bezdomnych ważniejsza od badań socjologicznych jest podstawowa refleksja na temat znaczenia domu w życiu człowieka.

Proces „uczenia się domu”, „zadomowienia” można opisać na wiele sposobów. W tym tekście zostanie zaproponowane rozumienie procesu zadomawiania przy pomocy trzech dopełniających się teorii. Pierwsza to koncepcja "miejsca i nie-miejsca antropologicznego" sformułowana przez Marca Augé4. „Nie-miejsce antropologiczne” to przestrzeń tranzytywna, która nie ewokuje procesu zadomawiania, nie zmusza do troski o nią, to przestrzeń, która nie usposabia do budowania relacji z innymi ludźmi. Współczesne miasta posiadają liczne „nie-miejsca”, które pogłębiają anonimowość, osamotnienie miejskie. Proces zmiany rozumienia mieszkania $z$ "nie-miejsca” w „miejsce” antropologiczne jest bardzo ważny w procesie zadomawiania bezdomnych.Zadomawianie rozumiane jako traktowanie określonego mieszkania jako własne prowadzi do przywiązania do miejsca, które ma charakter - jak napisze Yi-Fu Tuan - „zakorzenienia w miejscu”'. Proces ten rozwija się w czasie i ma charakter „doświadczenia intymnego”, które jest rodzajem relacji z przestrzenią postrzeganą jako własna i wytwarza w świadomości mieszkańca, zgodnie z określeniem tego samego badacza, „konstrukcję pojęciową”, przestrzeń nowego mieszkania zostaje udomowiona ${ }^{6}$. Początkiem tego procesu jest odkrycie siebie jako „ciała-w-świecie” oraz dbałość najpierw o własne ciało, a wtórnie o przestrzeń wokół niego. Odkrywanie jakiejś przestrzeni jako własnej rozpoczyna się od odkrywania własnego zamieszkiwania w świecie przez ciało ${ }^{7}$. Prowadzenie bezdomnych od odkrycia zamieszkiwania w ciele do zamieszkiwania w domu, od troski o przestrzeń ciała i wokół niego do troski o własne mieszkanie, to kierunki programu wychodzenia $\mathrm{z}$ bezdomności zaproponowane przez Dzieło.

\section{Zarys historii pomocy oferowanej przez Dzieło}

Dzieło Pomocy św. Ojca Pio jest instytucją stosukowo młodą, lecz nawiązującą do długiej tradycji pracy charytatywnej wspólnoty Braci Mniejszych Kapucynów, żyjących i posługujących w klasztorze krakowskim tego zakonu. Klasztor kapucyński w Krakowie powstał w 1799 roku i nieprzerwanie prowadził działalność charytatywną, której jednym z przejawów było wydawanie żywności i odzieży biednym przy furcie klasztornej. W latach II wojny światowej kapucyni udzielili schronienia w klasztorze kilkunastu rodzinom wysiedlonym przez okupanta z Poznańskiego.

Po wojnie wspieranie ubogich przez zakonników było kontynuowane. Choć oficjalna propaganda wieściła brak bezdomnych w socjalistycznym państwie, to jednak

\footnotetext{
Augé 2011.

Yi-Fu Tuan 1987, s. 247.

6 Yi-Fu Tuan 1987, s. 247.

7 Galimberti 1996.
} 
praktyka posługi przy furcie krakowskiego klasztoru wskazywała na co innego. Bracia kapucyni rozdawali coraz więcej żywności, zwłaszcza zupy, udzielali bądź organizowali pomoc medyczną zgłaszającym się bezdomnym, którzy zwykle nie posiadali ani ubezpieczenia zdrowotnego, ani często nawet podstawowych dokumentów tożsamości. Znaczącą postacią stale udzielającą pomocy bezdomnym był brat Konrad Stanisław Rogoziński, który przez ponad 40 lat posługiwał na furcie klasztoru krakowskiego ${ }^{8}$.Jego zaangażowanie w pracę z ubogimi, aktywność na rzecz klasztoru (był z zawodu zdunem, a z zamiłowania szklarzem), jak również specyficzne poczucie humoru uczyniły z niego postać legendarną. Jego specyficzne powiedzonka - kwiatki - krążą do dziś wśród braci kapucynów ${ }^{9}$. W pomoc ubogim byli szczególnie zaangażowani młodzi bracia - klerycy studiujący teologię i przygotowujący się do święceń kapłańskich. Obok roznoszenia obiadów do kilkudziesięciu ubogich osób w okolicy klasztoru na ulicy Loretańskiej, udzielano również wielorakiej pomocy bezdomnym. Angażowano w nią również zaprzyjaźnionych lekarzy i prawników.

Rozdawanie żywności przy furcie zaczęło napotykać poważniejsze trudności w latach dziewięćdziesiątych ubiegłego wieku. Proszących o żywność przybywało, z tego też powodu konsumpcja posiłku przy furcie odbywała się w coraz gorszych warunkach. Zdarzały się również sytuacje konfliktowe pomiędzy oczekującymi na jedzenie, co powodowało problemy w funkcjonowaniu furty klasztornej. Zdarzało się, że dostęp do niej był szczególnie kłopotliwy, zwłaszcza w godzinach południowych.

Przełożeni Zakonu zdecydowali o zmianie miejsca i sposobu udzielania pomocy bezdomny i ubogim. W 1999 roku w ogrodzie klasztoru kapucynów w Krakowie stanął barak służący za stołówkę, nazwany Kuchnią świętego Łazarza (przezwany dowcipnie „kapfoodem”) oraz drugi, który mieścił łaźnię dla bezdomnych. Zmiany te stały się inspiracją do powstania specjalnej instytucji powołanej do istnienia decyzją Ministra Prowincjalnego brata Jacka Waligóry dnia 23 grudnia 2001 roku. Kuchnia istnieje odtąd jako wewnętrzna jednostka Prowincji Krakowskiej Zakonu Braci Mniejszych Kapucynów. Powstały wówczas pierwsze plany dotyczące rozwoju organizacji i utworzenia miejsca świadczącego profesjonalną pomoc osobom bezdomnym.

1 czerwca 2004 roku nastąpiła zmiana nazwy z Kuchnia św. Łazarza na Dzieło Pomocy św. Ojca Pio. 15 września tego samego roku Dzieło uzyskało status organizacji pożytku publicznego. $Z$ upływem lat zwiększa się liczba darczyńców i przyjaciół wspierających regularnie jej bieżące działania i odważne plany. 23 września 2010 roku na miejscu baraków w przyklasztornym ogrodzie uruchomiono pierwsze Centrum Pomocy. Osoby najuboższe mogą tu skorzystać z profesjonalnego wsparcia pracowników socjalnych, doradców zawodowych, lekarza psychiatry i psychoterapeutów oraz zasięgnąć porady duchowej u kapłanów. W nowej lokalizacji powstają i rozpoczynają swoje regularne

8 Gadacz 1986, t. 1, s. 220n;

9 Niektóre z jego powiedzonek udało się zebrać i opublikować. Śliwińska, Śliwiński 2000. 
spotkania grupy wsparcia. W maju 2012 roku otwarto pierwsze w Krakowie mieszkania wspierane dla kobiet i rodzin, które straciły dom. Dla wielu osób mieszkania te są ostatnim przystankiem na drodze do pełnej samodzielności.

23 września 2013 roku aktywowano drugie Centrum Pomocy. W budynku przy ul. Smoleńsk 4 osoby bezdomne mogą bezpłatnie skorzystać z łaźni, pralni i garderoby, otrzymać pomoc medyczną w przychodni Stowarzyszenia „Lekarze Nadziei” oraz zjeść ciepły posiłek w Kuchni Społecznej im. S. Samueli, prowadzonej przez siostry felicjanki. W nowym Centrum można również uzyskać pomoc w znalezieniu pracy. 1 marca 2016 roku rozpoczęło działalność Centrum Integracji Społecznej (CIS), uruchomione przy Dziale Aktywizacji Zawodowej. Dzięki pracy CIS-u osoby bezdomne są objęte wszechstronnym wsparciem w powrocie do pracy i odbudowywaniu więzi społecznych ${ }^{10}$.

\section{Program indywidualnego wychodzenia z bezdomności}

Pomoc mieszkaniowa jest uzupełnieniem bogatej oferty proponowanej przez Dzieło Pomocy. Wsparcie w okresie korzystania z mieszkania treningowego (wspieranego) to praca zespołu interdyscyplinarnego, w którego skład wchodzą pracownicy socjalni, asystenci, doradcy zawodowi, psychologowie, psychoterapeuci. Połączenie tych dwóch form - mieszkania i pomocy zwiększa szansę usamodzielnienia - rozumianego jako samodzielne zamieszkanie. Dzieło Pomocy prowadzi mieszkania wspierane rozproszone. Są to pojedyncze mieszkania w różnych częściach Krakowa. Model ten - mimo trudności - daje większą możliwość integracji społecznej w odróżnieniu od innych form. Możliwość zamieszkania w naturalnym środowisku i standardowych warunkach mieszkaniowych, tj. w samodzielnych lokalach zapewnia osobom korzystającym z nich namiastkę domu.

W czasie pobytu w mieszkaniu osoby przygotowujące się do samodzielnego życia, uczą się pokonywania codziennych problemów, współpracy w utrzymaniu powierzonej przestrzeni. Czasami niektórych umiejętności muszą się nauczyć lub je sobie przypomnieć.

Specjaliści pomagają podopiecznym w zmierzeniu się z przeszłością oraz poukładaniu życia na nowo. Chociaż każda osoba, która straciła dom pragnie go odzyskać, to jednak taka zmiana generuje duże lęki. Każdy z lokatorów wspólnie z pracownikiem Dzieła opracowuje Indywidualny Program Wychodzenia z Bezdomności, dopracowany do możliwości każdego z mieszkańców. Określa on kolejne kroki pomagające w zmianie życiowej oraz potrzebny na nie czas. Uczestnicy programu mieszkań wspieranych Dzieła Pomocy św. Ojca Pio otrzymują pomoc mieszkaniową - czasowy pobyt w niezależnych lokalach mieszkaniowych na zasadach określonych w umowie i regulaminie. W ciągu całego procesu wychodzenia $\mathrm{z}$ bezdomności korzystają z poradnictwa $\mathrm{i}$ wsparcia socjalnego, zawodowego, psychologicznego, prawnego, a jeśli chcą i religijnego udzielanego przez zespół pracowników. Dla każdego uczestnika programu zostaje

${ }^{10}$ Dzieto Pomocy św. Ojca Pio, 01.12.2018. 
sformułowany indywidualny program wychodzenia z bezdomności - plan pomocowy, którego wspólna realizacja ma prowadzić lokatorów do życiowej samodzielności. Osoby uczestniczące otrzymują także wsparcie grupowe - realizowane w ramach społeczności mieszkańców, warsztatów oraz grup wsparcia, jak również pomoc w usamodzielnieniu się i w znalezieniu samodzielnego mieszkania na wolnym rynku. Po opuszczeniu lokalu uczestnicy programu mieszkań wspieranych są jeszcze przez sześć miesięcy pod opieką zespołu pracowników Dzieła Pomocy św. Ojca Pio.

\section{Uczenie się przez zamieszkanie}

Obserwacja procesu przygotowania bezdomnego do zamieszkania, a następnie samego zamieszkania w mieszkaniu wspieranym pozwala wyznaczyć pewne jego fazy, które choć różne w przypadkach poszczególnych osób, nieodmiennie się powtarzają. Pierwsza z nich polega na uświadomieniu sobie i przyjęciu konsekwencji z faktu posiadania własnego mieszkania, druga zaś na zmianie stosunku wobec innych osób, społeczności oraz różnych przestrzeni. Na rozpiętość czasową poszczególnych faz wpływa zawsze historia poszczególnej osoby lub grupy, a zwłaszcza okres doświadczonej bezdomności.

\section{Faza pierwsza - „troska”}

Przygotowywanie bezdomnego do zamieszkania, czyli wyjścia z bezdomności przebiega wielowarstwowo. Ma on odkryć i zaakceptować potrzebę i konieczność dbałości o własne (za)mieszkanie. Proces ten jest złożony, a u jego podstawy znajduje się troska o własne ciało ${ }^{11}$. Fundamentalny sposób zamieszkania w świecie, jakim jest cielesność wymaga często sporego trudu od bezdomnego i towarzyszącego mu zespołu. Kontakt ze współlokatorami tej samej klatki schodowej i szerzej - całego obejścia - wymusza podjęcie wysiłku utrzymania czystości i higieny ciała oraz używanych ubrań. Brak stygmatyzującego wyglądu i zapachu są warunkiem jakiejś formy integracji ze współlokatorami, a więc również podstawowym warunkiem sukcesów w nauce zamieszkiwania. Wsparcie pracowników Dzieła wraz z pomocą medyczną jest szczególnie ważne w mobilizacji do zachowania podstawowej higieny osobistej i ewentualnego leczenia schorzeń skórnych występujących często u osób doświadczonych bezdomnością.

Równolegle z troską o własne ciało, bezdomny uczy się dbać o swoje mieszkanie. Jest to kolejna przestrzeń zadomawiania. Zwykle zaczyna się to od wyznaczenia granic „mojego mieszkania” i fragmentarycznego jego zawłaszczenia. Ograniczenie przestrzenne jest oczywiste, znacznie trudniej jest przyswoić sobie konieczność szczególnego traktowania własnego mieszkania, a więc przestrzeni uznanej za własną. Chodzi bowiem o wypracowanie u osób czasowo bezdomnych odpowiedzialności za używany lokal. Dość długo trwa zwykle nabywanie świadomości związanej z utrzymaniem porządku w mieszkaniu. Nie wynika to jedynie z braku odpowiednich nawyków, ale także

${ }^{11}$ Galimberti 1996, s. 41. 
z traktowania każdej zamieszkiwanej przestrzeni jako tymczasowej, tranzytywnej. Powoli wypracowywane są nawyki regularnego sprzątania całego mieszkania, dbałości o czystość przez niewchodzenie do pomieszczeń w zabrudzonym obuwiu czy też regularne sortowanie i usuwanie odpadków. Uczestniczący w programie uczy się też odpowiedzialności za koszty utrzymania. Od otrzymywanego wynagrodzenia za pracę jest odciągana opłata za mieszkanie (czynsz oraz media) i składana na koncie uczestniczącego w programie. W razie pomyślnego jego zakończenia odkładane kwoty stanowią kapitał początkowy mieszkającego już samodzielnie adepta programu.

\section{Faza druga - „uczestnictwo”}

Zamieszkać w swoim domu, mieszkaniu, to także podjąć trud bycia $\mathrm{z}$ innymi. Ksiądz Tischner słusznie zauważył, że „człowiek nie może zadomowić się w samotności” ${ }^{12}$. Można powiedzieć, że mieszkać oznacza także zamieszkiwać obok innych i wraz z nimi. Zaproponowany przez Dzieło model wychodzenia z bezdomności kładzie duży nacisk na budowanie relacji z innymi ludźmi, w tym także relacji sąsiedzkich. $Z$ tej racji mieszkania treningowe nie są położone obok siebie, lecz rozsiane po różnych osiedlach. Korzystanie ze wspólnych przestrzeni - klatka schodowa, pralnia, strych - daje okazje do nawiązywania kontaktów, udzielania i korzystania z pomocy sąsiedzkiej, czy też po prostu do zwyczajnych codziennych spotkań przy wejściu, w windzie, pralni itd. Sytuacje są okazją do nawiązywania znajomości, wymiany potrzebnych informacji. Pracownicy Dzieła opowiadali o uczestnikach programu wychodzenia $z$ bezdomności darzonych szczególną sympatią sąsiadów. Zwracali też uwagę, że wielu ich podopiecznych cechowała olbrzymia nieufność wobec ludzi, wynikająca z krzywd doznanych w czasie bezdomności. Pracownicy wspominali także o jednym, ale szczególnym przypadku, gdy jeden z uczestników programu próbował stworzyć w mieszkaniu chronionym melinę pijacką. Usiłowania te doprowadziły do przerwania jego uczestnictwa w programie i usunięciu $z$ mieszkania chronionego.

\section{Dom jako zadanie}

Profesjonalnie sformułowane ogólne zasady towarzyszenia bezdomnym w „uczeniu się mieszkania” lub „przypominaniu sobie zasad mieszkania” nie oddają dynamiki zaangażowania się pracowników Dzieła w pomoc oraz związanych z nią, czasami nietypowych, sytuacji. Rozmowy z towarzyszącymi bezdomnym w procesie zadomawiania uświadamiają, że okres przebywania w mieszkaniu wspieranym jest dla uczestnika programu bardzo intensywnym czasem szkoleniowym. Obok dbania o higienę osobistą oraz o mieszkanie, osoby uczestniczące w programie uczą się wykonywania regularnej pracy, a więc obowiązków zmuszających do innego niż w życiu bezdomnego gospodarowania czasem, dbałości o własną higienę i zdrowie, gospodarowania pieniędzmi, ale

\footnotetext{
${ }^{12}$ Tischner 1998, s. 96.
} 
również budowania relacji ze współpracownikami i sąsiadami. Uczenie się, czym jest własny dom nie jest łatwe. Wszak nie jest to tylko zabezpieczona od negatywnych wpływów atmosferycznych przestrzeń. Dom bowiem to również szczególna przestrzeń bycia $\mathrm{z}$ innymi - najbliższymi ludźmi.

Przestrzenią człowiekowi najbliższą jest dom. Wszystkie drogi człowieka przez świat mierzą się odległością od domu. Widok z okien domu jest pierwszym widokiem człowieka na świat. Człowiek spytany, skąd przychodzi - wskazuje na dom. Dom jest gniazdem człowieka. Tu przychodzi na świat dziecko, tu dojrzewa poczucie odpowiedzialności za ład pierwszej wspólnoty, tu człowiek poznaje tajemnice rzeczy - okna, drzwi, łyżki - cieszy się i cierpi, stąd odchodzi na wieczny spoczynek. Mieć dom, znaczy: mieć wokół siebie obszar pierwotnej swojskości. Ściany domu chronią człowieka przed srogością żywiołów i nieprzyjaźnią ludzi. Umożliwiają życie i dojrzewanie. Mieszkając w domu, człowiek może się czuć sobą u siebie. Być sobą u siebie to doświadczać sensownej wolności. Dom nie pozwala na swawolę, nie oznacza też niewoli. Domowa przestrzeń, to przestrzeń wielorakiego sensu ${ }^{13}$.

Trudno nie zakończyć opowieści o programie wychodzenia $\mathrm{z}$ bezdomności pytaniem o efektywność tak zorganizowanej pomocy. Od maja 2012 roku do grudnia 2015 z programu mieszkań wspieranych skorzystało 49 osób (31 dorosłych i 18 dzieci). Usamodzielniło się 15 osób dorosłych i 8 dzieci. W programie wychodzenia z bezdomności proponowanemu przez Dzieło Pomocy św. Ojca Pio można uczestniczyć wielokrotnie, nikt więc nie pozostaje definitywnie wyłączony z możliwej pomocy.

\section{Bibliografia}

Augé M. 2011, Nie-miejsca. Wprowadzenie do antropologii hipernowoczesności, thum.

Chymkowski R., PWN, Warszawa.

Gadacz J. L. 1986, Stownik polskich kapucynów t.1-2, Wydawnictwo OO. Kapucynów, Wrocław.

Galimberti U. 1996, Il corpo, Il Saggiatore, Milano.

Oliwa-Ciesielska M. 2004, Piętno nieprzystosowania, UAM, Poznań.

Śliwińska T., Śliwiński J.P. 2000, Kwiatki dla świętego Franciszka, Księgarnia Świętego Wojciecha, Poznań.

Tischner J. 1998, Filozofia dramatu, Znak, Kraków.

Tuan Yi-Fu. 1987, Przestrzeń i czas, tłum. Morawińska A., Państwowy Instytut Wydawniczy, Warszawa.

Weil S. 1986, Świadomość nadprzyrodzona. Wybór myśli, tłum. Olędzka-Frybesowa A., wyb. Nowak J., PAX, Warszawa.

Dzieto Pomocy św. Ojca Pio, http://dzielopomocy.p1/, 01.12.2018.

13 Tischner 1998, s. 187. 